\title{
Article \\ Proficiency Level of Leadership Competences on the Initial Training Course for Firefighters-A Case Study of Lisbon Fire Service
}

\author{
João Carolino ${ }^{1, *}$ and Carlos Rouco ${ }^{2}$ (D) \\ 1 Regimento de Sapadores Bombeiros de Lisboa, ERSB, Rua Doutor José Espírito Santo, \\ 1950-096 Lisboa, Portugal \\ 2 TRIE, Universidade Lusófona de Humanidades e Tecnologias, Campo Grande 376, 1750-364 Lisboa, Portugal; \\ carlos.rouco@ulusofona.pt \\ * Correspondence: joao.carolino@cm-lisboa.pt; Tel.: +351-966151955
}

check for updates

Citation: Carolino, J.; Rouco, C. Proficiency Level of Leadership Competences on the Initial Training Course for Firefighters-A Case Study of Lisbon Fire Service. Fire 2022, 5, 22. https://doi.org/ $10.3390 /$ fire5010022

Academic Editor: Natasha Ribeiro

Received: 3 January 2022

Accepted: 8 February 2022

Published: 11 February 2022

Publisher's Note: MDPI stays neutral with regard to jurisdictional claims in published maps and institutional affiliations.

Copyright: (C) 2022 by the authors. Licensee MDPI, Basel, Switzerland. This article is an open access article distributed under the terms and conditions of the Creative Commons Attribution (CC BY) license (https:// creativecommons.org/licenses/by/ $4.0 /)$.

\begin{abstract}
Leadership competence development in the Portuguese fire services is an area to be explored and one where we must obtain more profound knowledge. The research seeks to identify the role of the initial training course for professional firefighters in the proficiency level of leadership competences in trainees at the Lisbon Fire Service. To achieve the objectives of the investigation, the researchers adopted a quantitative method with a longitudinal case study research design, using a questionnaire of leadership competences, applied to 126 trainees of the Initial Training Course for professional firefighters from Lisbon Fire Service (case study), at three different moments during a one-year training period (longitudinal study). From the obtained results, it was concluded that the leadership competences with the highest level of proficiency at the end of the course are problem solving, participatory leadership, delegative leadership, conflict management, influence by example, task orientation, decision making, vision and proactivity.
\end{abstract}

Keywords: leader; leadership; competence; professional training; firefighter

\section{Introduction \\ 1.1. Leadership in Firefighters}

The development of leadership skills is a topic that has been studied over the last few years, with some preponderance in some civil protection agents, such as the armed forces and security forces. This theme, having not yet been approached with the desired depth in Portugal, in the field of firefighters, whether professionals or volunteers, is presented as fundamental, considering the three major modalities of training, as follows: initial career entry training, ongoing training, and training for career progression. In the context of forest fires, commanders with the best leadership competences increase their performance in protecting people and property, by being more capable of taking decisions in complex environments, in a short period of time and with limited information [1].

Competences are intrinsic characteristics that reflect the ability and capacity to perform an activity, regardless of the situation or environment [2], and they have a causal relationship to effective or superior performance, in each function or situation, within pre-defined criteria [3]. This set of behaviors are related to each other, which direct the individual to a certain action, and which defines their suitability to a specific situation [4], validated by the existing criteria to ensure that it is not merely a question of casuistic behavior cases [5]. Competences can be categorized into transversal or differentiating [3], and where the inputs that the individual brings into the organization and what is extracted from this competence, in terms of output, are considered [6].

Different studies have advocated the existence of structural, common, and permanent leadership competences, as well as specific competence, whose training and development 
must be carried out when there is specific training according to the function and career [7], with a variation in the degree of importance given to the different leadership competences as a function of the leader's evolution or position in the hierarchical structure [8]. Looking at the Portuguese panorama, studies related to leadership in firefighters are still incipient and indicate the exercise of situational leadership, with a strong tendency between leadership and employee motivation, where the figure of the commander is considered as that of a democratic leader [9]. The relationships developed between the leader and those led within the firefighter teams are positively related to satisfaction, the belief in collective selfefficacy and specialization, but unrelated to the dimensions of credibility and coordination, where the best predictor for the performance of teams is satisfaction [10]. Leadership involves the structuring or restructuring of a given situation and its relationship between expectations and perceptions [11], focusing on the long-term development of people and organizations, so they can adapt, change, prosper and grow [12], leading to the construction or transformation of systems and expanding territories [13].

The role of leadership goes far beyond the leader-follower relationship, involving different processes that affect not only the leader's personal development but also his relationship with others [14]. Effective leadership includes the following three variables: the characteristics of the leader, the followers, and the situation. This starts with the interaction that their own values have in filtering the stimuli they receive and how they contribute to the processing of appropriate behavior [15]. Leadership is, thus, dependent on its own framework [11] and the way in which the challenges presented by it are taken on at a personal level [12].

The concept of reference to third parties through the individual's traits and their role in the recognition by others [16] refers to the modeling effect [17], demonstrated in the context of training and development in management [18], and is recognized as the form of leading in a military context [19]. This idealized influence is considered adequate in the definition of the charismatic model for the followers [20], being also dependent on the type of collaborators and their dimensions [21,22]. The leader's intellectual stimulation is the starting point for agitation and change in the followers' perspective, regarding problem solving, imagination and thinking, beliefs and values [23]. The leader is seen as the backup and support [24] in relation to conflict resolution [25], with a role to play at different times and according to the maturity of the employees [26]. The perspective that leadership can be exercised with confidence, in a competitive and task-oriented, decisive, assertive and objective way $[27,28]$, led some researchers to disagree with the comparison between men and women, concluding that there are no differences between them $[11,29,30]$, while others state that there are differences for some competences, in certain situations, especially those in which orientation for people is necessary [31-33]. To traits such as intelligence, confidence, humanity, courage, and severity, considered as predictors of leadership [34], knowledge, judgment, vision, initiative, integrity, and adaptability were added [11].

Globally, the leadership approach within firefighters is nothing new [35]. Research suggests that the success of fire services is related to an effective form of leadership and the definition of objectives, planning and activities [36], ensuring, from an organizational point of view, a structure, processes, and behaviors, as pillars on which leaders make their way [37]. This path very often depends on the dimension of leadership that each individual leader can develop, thus, limiting the guarantees that progress is maintained when there is leadership change, particularly in environments that change dramatically [38,39]. The education and experience needed to lead are attributes more difficult to obtain than the education and experience to manage [40]. This type of performance can also be enhanced by interoperability with other agents and for that, shared vision, strong leadership, and commitment are referred to as facilitating elements in reducing the impact between different structures [41].

The relationship-centered approach and the goal-directed approach are positively related to employee satisfaction [42] and contribute to the motivation, morale, and commitment of employees [43]. 
Firefighters appreciate leaders who are considerate of the safety of their operatives, that lead by example and who effectively communicate their concerns about needs and expectations, while demonstrating their commitment and reciprocity [44-46].

Organizations are more successful when their leaders have within themselves a set of characteristics that enhance the motivation and greater commitment of their employees $[9,47]$, making leadership an essential element in emergency situations, such as those in which a fire service operates [36]. A correlation between diminished leadership skills and the increased danger to which citizens and firefighters are exposed is suggested [48-51]. The way in which many fire brigades provide training in leadership contributes to this situation, sometimes creating imbalances in the definition of the criteria used and shown in the examples provided [52-54].

Within the protection and rescue activity, and specifically when leading firefighters, the lack of preparation/training in leadership, the operation under the effect of extreme stress and the ambiguity of authority are factors that contribute to decision-making below the expected standard, placing at risk not only the mission, but ultimately the life of the elements that operate under the influence of the leader [55]. On the other hand, by basing promotions solely on seniority, it is necessary to find a balance between age or length of stay in the organization and the generational differences existing within it, to take advantage of the best that the different generations have and can bring to the future of firefighters. If, on the one hand, younger generations have greater affinity with new technologies, the experience held by previous generations is an asset too expensive to be wasted. That is, younger generations tend to show greater levels of openness to change and new approaches, with a willingness to take risks, optimism and enthusiasm, ability to motivate others, search for responsibility, vigor for high performance and work directed for self-development and self-promotion. Meanwhile, at the other extreme, there are older generations who have higher levels of predictive analysis capacity for problems based on acquired experience, risk minimization, calm and discretion, in-depth knowledge of the area of activity and use of this advantage in approaching and solving problems, as well as cooperation, delegation and a greater degree of empathy and concern, which is reflected in work more directed towards the development of others [56-59].

To these factors are added the tasks of protecting and saving threatened lives, the stabilization of incidents, the suppression of losses, the control of fires and the conservation of property [60], which cannot be disconnected from the operating environment in which they occur [61].

This framework contributes to the fact that, organizationally, promotion for the functions where leadership will be practiced is instigated even before being given the necessary tools for this $[35,62]$. This perspective is consistent with that of other researchers who indicate that the typology of experience that influences the exercise of leadership cannot be considered transversal throughout the career; that is, for different moments of the career and of the leadership exercised. Furthermore, the acquisition of competences associated with experiences is changed, obtaining better results at an early stage of the career, with the use of simple experiences that allow for the global perception of the organization and, only then, progress to more complex experiences [63], based on leadership as a continuous and dedicated learning process throughout life, which allows for the existence of competences that are present at the beginning of the career while others will be developed and manifested over time, through education, training and experience [64]. Studies identify the existence of a relationship between education and competences such as integrity, charisma, orientation towards people and interpersonal relationships [65-69]. On the other hand, education also has an inverse relationship with factors considered to inhibit the exercise of effective leadership, such as autocracy, self-centeredness and self-protective or appearanceprotecting behaviors [70]. This type of limitation, in certain security contexts, leads to prospects of invincibility, massive strength, independence and quick response that can compromise the best interests of organizations [71], which can lead to organizational failure or the destruction of promising careers within the fire service, either by abandonment or by constant promotion without the proper competences [72]. 
The importance of hierarchical leadership is referred to as important and necessary in organizations $[73,74]$, so that, for firefighters, as a hierarchical structure, it can be developed using various aspects of different theories, in a way to find an approach that best meets the needs of this type of organization [36].

The characteristics and attributes necessary for effective leadership in the operational environment of firefighters, particularly in times of uncertainty, are self-confidence, enthusiasm, effective communication, knowledge, vision, integrity, courage, honesty, pride, determination, faith, vigor, judgment, tact, endurance, initiative, responsibility, ethics, altruism, reliability, loyalty, consideration, self-discipline, and the desire to learn [75].

The leadership model for the fire service must have, as attributes, the ability to generate loyalty, foster awareness of everyone about their role in the team, intellectual stimulation and charisma that allows them to capture the attention of their subordinates [36]. The identification of measurable functional requirements that allow for the demonstration of the individual's performance leads to highlighting commitment, diversity, integrity, openness to change, trust, resilience, teamwork, communication, problem solving, situational awareness (both politically and organizationally), planning and proactiveness, as attributes and qualities of the leader [76]. On the other hand, education, experience, professional development, critical thinking, communication, and mentoring are elements considered necessary for the development of leadership in future leaders of the fire service [71]. For this, it is equally necessary to have a work environment that allows the interaction of different systems, the continued search for involvement and accountability, both for the organization and individuals, in what are the competences of conflict management, in a way to secure the advantage over threats [52].

The similarity and analogy between the context of the fire service and the military is considered by different authors $[48,52,60,77,78]$, and the competences that serve as a reference for the development of leadership are communication, supervision, teaching and advice, team development, technical and tactical proficiency (as proficiency represents the grade of ability to perform a specific task), decision making, planning, use of available systems and ethics [79].

The leadership competences management model [80], shown in Table 1, validated for the Portuguese population, and already applied to different contexts, has proved to be effective, presenting the same competences mentioned by other authors [7,8,79-83], such as determination and perseverance, communication, problem solving, self-confidence, vision, proactivity, assertiveness, decision making and the development of others.

Table 1. Leadership competences management model [80,84].

\begin{tabular}{|c|c|c|}
\hline $\begin{array}{l}\text { Domain of } \\
\text { Competence }\end{array}$ & Competence Type & Competence \\
\hline Personal & Cognitive & $\begin{array}{c}\text { Courage; Self-confidence; Self-control; Flexibility and } \\
\text { adaptability; Determination and perseverance; } \\
\text { Optimism and enthusiasm; Consideration; } \\
\text { Transparency; Proactivity. }\end{array}$ \\
\hline Social & Relationship with others & $\begin{array}{l}\text { Participatory leadership; Delegative leadership; } \\
\text { Influence by example; Empathy; Openness to } \\
\text { multiculturalism; Recognition and positive feedback; } \\
\text { Communication; Assertiveness; Teamwork; } \\
\text { Interpersonal relationships; Developing others; } \\
\text { Orientation to human relationships. }\end{array}$ \\
\hline Functional & $\begin{array}{l}\text { From work, activities, } \\
\text { and tasks }\end{array}$ & $\begin{array}{l}\text { Decision making; Problem solving; Task orientation; } \\
\text { Technical and professional aptitude. }\end{array}$ \\
\hline Organizational & Management & Vision; Conflict management. \\
\hline
\end{tabular}

\subsection{Vocational Training Program}

In learning development, there are the following two factors to consider: individual learning and organizational learning. Individual learning presents a set of characteristics considered as main (it is an active process, driven by objectives, with constructive and cumulative capacity and which must allow a diagnostic and reflective assessment in accordance with the defined purposes [85]). The relationship between the two clearly 
demonstrates the influence that the former exerts on the latter, namely in its development through models that start from the processes of the learning domain, applicable to the individual, and directly transforms them into the domain of organizational learning [86-89].

Organizational learning takes place at the following three different levels: at the organizational level, at the group level and at the individual level. These different levels provide a division in the fields of work for organizational psychologists (organizational and group level) and educational psychologists (individual level). Being opposite fields, they are mutually necessary and not mutually exclusive. Individual learning, to be effective, needs support and organizational context, while organizational learning depends on the effectiveness of individual learning [90].

As there are several currents of thought, it is important to list the main theories of learning, as follows: the behaviorist theories, which include authors such as Pavlov, Watson, Thorndike and Skinner [91-94], who, having different perspectives on the behaviors studied, contribute to the development of the behavioral approach and frame the learning as a form of conditioning, resulting from the association of stimuli and reactions that, given the surrounding context, can be reinforced or eliminated, according to the results obtained; the cognitive theories, where the focus is on the learning process at the expense of the product obtained, these theories being divided into form or configuration theory and field theory, giving the first emphasis to the structure of learning and the way in which it is organized, as well as the relationships that result from this interaction [95-98], and on the other hand, field theory, in which the attribution of meaning is an elementary condition, resulting from the change in the individual's knowledge structure, as well as the way in which he/she perceives the context, chooses and organizes objects and events [99-104]; and the biological theory of self-production, initially enunciated by Maturana and Varela [105], based on studies by Bateson, Bertalanffy and Heiz von Foerster [106-108], which postulate the non-existence of separation between who produces and what is produced, this being a set of processes created by the individual who maintains the organism's survival, constituting its knowledge and adapting to external disturbances [109].

The existence of different theories in the learning approach leads to a reflection on more formal teaching models, placing the process of acquisition and the construction and restructuring of knowledge under the control of the learning subject, thus, becoming an actor, decision maker and conductor of their knowledge and its transformation, which is a process of interaction and mutual influence in the construction and development of the individual and the world around them.

As leadership theories evolved, so did learning/development theories, presented in Table 2, developing the belief that the ability to be a good leader can be learned, even though some people have a greater innate ability to lead.

Table 2. General theories of leadership skills development [110].

\begin{tabular}{|c|c|c|}
\hline Theories & Description & References \\
\hline Behavioural & $\begin{array}{l}\text { Learning is an experience through conditioning, } \\
\text { reinforcement, or repetition that leads to a } \\
\text { permanent change in behaviour; learning is active } \\
\text { and not passive. }\end{array}$ & $\begin{array}{l}\text { Watson, 1913; } \\
\text { Hartley, 1998; } \\
\text { Jordan et al., } 2008 \text {. }\end{array}$ \\
\hline Cognitive & $\begin{array}{c}\text { It focuses on internal events, i.e., making mental } \\
\text { connections and inferring or building knowledge. } \\
\text { How information is conveyed is as important as } \\
\text { what is conveyed. }\end{array}$ & $\begin{array}{c}\text { Harteley, 1998; } \\
\text { Jordan et al., } 2008 .\end{array}$ \\
\hline Constructivism & $\begin{array}{l}\text { It goes beyond knowledge acquisition to consider } \\
\text { how learning is actively constructed by combining } \\
\text { new information with existing knowledge. }\end{array}$ & $\begin{array}{c}\text { Cooper, 1993; } \\
\text { Bruner, 1966; } \\
\text { Ford and Lawler, } 2007 .\end{array}$ \\
\hline Social/Situational & $\begin{array}{l}\text { Recognizes the importance of social interactions, } \\
\text { environments and factors in skill learning and } \\
\text { knowledge acquisition. Learning can be based on } \\
\text { shared experiences. }\end{array}$ & $\begin{array}{l}\text { Durkeim, 1956; } \\
\text { Bandura, } 1986 .\end{array}$ \\
\hline Transformational & $\begin{array}{l}\text { It relies on critical reflection in response to political } \\
\text { or social experiences and structures. Strives to create } \\
\text { more effective personal or organizational change. }\end{array}$ & $\begin{array}{l}\text { Mezirow, 1997; } \\
\text { Musselwhite, 2006; } \\
\text { Prandini et al., 2012; } \\
\text { Vellner, 2015. }\end{array}$ \\
\hline
\end{tabular}


The approach to considering these theories in competence development is one of learning outcomes; the knowledge, behaviours, attitudes, and values that a trainee will be able to demonstrate in the workplace upon completion of the learning process. The classic work on learning outcomes is that of Bloom et al. [111], who identified the following three learning domains: cognitive (mental skills, knowledge); affective (attitudes, emotions); and psychomotor (capacities or aptitudes).

The greatest emphasis on the development of leadership skills is based on constructivist and transformational learning theories, encouraging the trainee to critically reflect and build new knowledge. According to Stone [112], there are three principles of the constructivist model of learning, which are as follows: understanding, which comes from interacting with the environment; cognitive conflict, which is the stimulus to learn and determines the nature of what is learned; knowledge, which evolves through social negotiation with the learning environment.

Jordan, Carlile and Stack [113] mentioned that "inviting leaders to become aware of their prejudices and perceptions, empowers them to create new knowledge, to become more self-aware and consequently change behaviors" [113].

They also stated that learning is not simply an activity carried out as part of a training program, but a lifelong process of investigation, practice, and reflection. This premise is increasingly associated with investigations that have been carried out in the field of leadership, in which it is currently a process of learning through experience, whether structured or not, formal or informal, inside or outside the formal learning environment [113]. Kolb's learning cycle is one of the main theories that defines experiential learning [114], as illustrated in Figure 1.

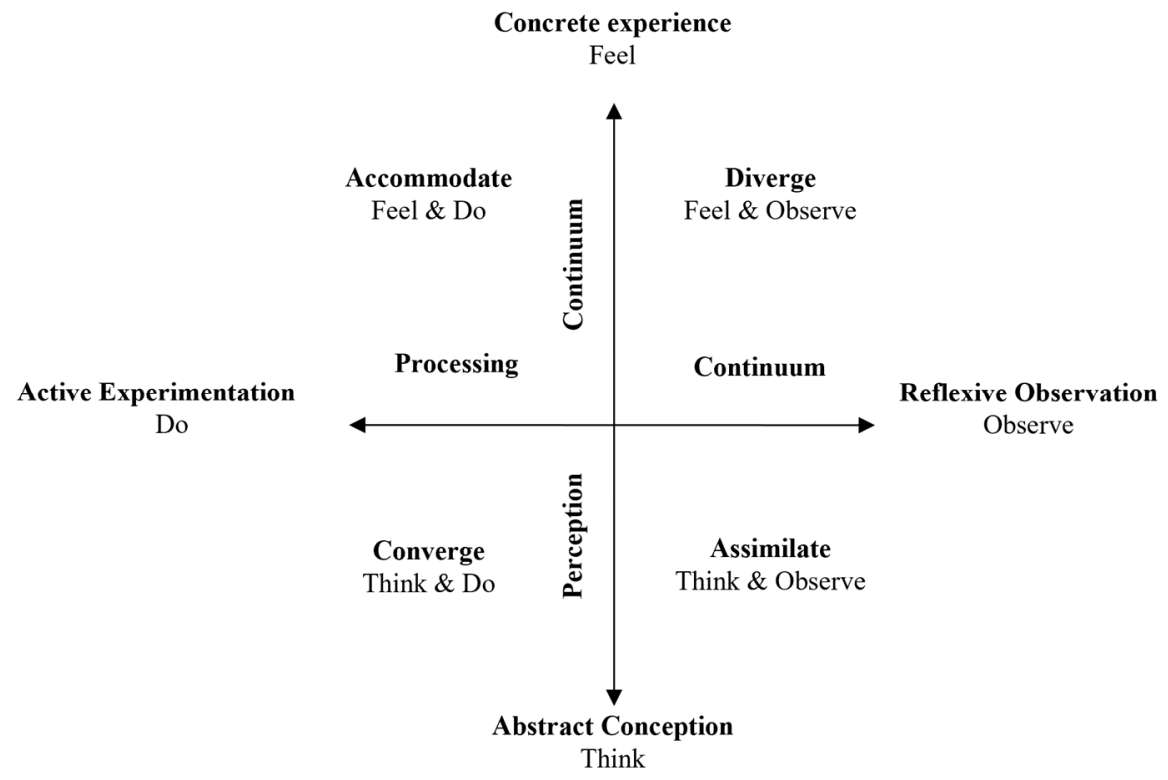

Figure 1. Kolb's Experiential Learning Cycle (Adapted from [114]).

In this theory, one of the critical elements is the ability to get trainees to reflect on the learning objectives and their transfer to the workplace.

Current learning is based on the centrality of the adult, integrated both in a system that provides training, facilitating self-learning, and in a training client system, which guarantees the existence of resources for the testing and application of knowledge [90]. This difference between systems is particularly important, considering that adult education is developed under the premise that adults learn using methods different from those used by children and young people $[115,116]$. This characteristic has led to the criticism of educational options in schools, based on the pedagogical concept, as the object of these options is precisely an adult individual with the ability to self-direct and self-develop $[117,118]$. 
Considering the competence in self-directed learning, adult education becomes more than a complement, a need for individual development in "learning to learn" [119], to ensure their survival in an environment in constant change and evolution, and with all the outdated inappropriateness that this dynamic has in the knowledge of each one.

This new reality shows the existing duality between training for qualification and competence training. If the first, more educated, focuses on the possession by the individual of the knowledge considered necessary for a given job, regardless of the function performed, the second aims at the ability to mobilize knowledge and intelligence at work, in order to build competences that encourage action in the face of the most complex and varied situations, fleeing from the rigidity of procedures that, in the face of a more demanding job market, become obstacles to organizational success [120,121].

Vocational training is defined as training aimed at providing the individual with competences with a view to exercising one or more professional activities [122], and within the scope of training in public administration, as the global and permanent process of the acquisition and development of competences required for the exercise of a professional activity or for the improvement of performance [123], which places the focus of human resource management on the continuous development of human capital, specifically on individual competences. This perspective integrates what, in the industrial era, was characterized as the life cycle of individuals, namely, by the existence of a school age, an age for work and an age for retirement, following the assumption of sequential articulation between each of these phases.

The Memorandum on Lifelong Learning proposes the integration of these ages, from a perspective of social and organizational development, framed by the school and oriented towards lifelong learning, in an alternating training system [124]. In the European Union, it is on this assumption and on this dynamic that we intend to structure the knowledge society in the future [90]. This model has not, according to the studies carried out, by itself ensured the supporting role that schools and training centers aspire to, to build the intended integrated system.

Within the main limitations, and attentive to the Portuguese reality, the orientation towards punctual and mainly technical development, accompanied by the absence of strategic planning, markedly directed towards the short term, and without evaluation criteria regarding the effectiveness and efficiency of organizations, hurts irremediably any attempt to add substantial gains to the organization, thus, limiting the development potential of this model [125].

Vocational training should be seen as a moment to reflect and investigate, with the purpose of ensuring learning that guarantees, more than mere suitability for work, the safeguarding of the protection and development of the workplace and its worker $[126,127]$.

The main purposes of professional training are to transmit knowledge and competences, adequate to the performance of the function; sustain the organizations strategy; increase the levels of motivation and satisfaction of assets, as well as their receptivity in acquiring knowledge and practical application; create opportunities in career development, thus, ensuring compatibility between individual expectations and organizational goals; integration in organizational change processes, through communication, participation and problem solving, wrapped in a perspective of continuous improvement; create a more competitive and qualified labor market, arising from the concept of the learning organization; facilitate the process of integration and socialization of assets, according to the required functions and outlined objectives [128-131].

In the national context, according to the National Qualifications System (NQS), initial training is recommended, which aims to acquire the knowledge, skills and abilities necessary for the exercise of professional activity, as well as continuing education, which enables the development of competences, aimed at adapting to changes in technology and organization, ensuring better employability, being carried out after leaving the education system or entering the labor market [122], thus, constantly following the individual throughout life. In this same context, and both in the general regime and in the regime of public admin- 
istration, the organization of training, defined according to specific characteristics, namely objectives, recipients, curricular structure, methodology and duration, is established as a training modality [122,123].

In the general regime, it is observed that in the constitution of the training modalities, the professional courses, apprenticeship courses, education and training courses, education and training courses for adults and technological specialization courses, are examples of modular training, while for training in public administration, the modalities of professional training are designated as follows: initial training, which may be of a general or specific nature, and the latter developed before admission or immediately after admission; continuous training, developed throughout the career and includes formal, non-formal and informal learning; training for a professional development, to strengthen competences, with the aim of integrating a different job position within the scope of a reorganization process.

Directing this investigation to the panorama of public administration, it is also important to mention that, in relation to professional training, it is subdivided into the following different types: short, medium or long-term training courses, associated with a final evaluative character; seminars, meetings, conferences, lectures, conferences or others, without an evaluative nature; internships, training workshops, communities of practice, mentoring, tutoring or other modalities not recommended in the previous [123].

In the training and development of human resources, the characterization of training, in terms of nature, purpose, form and subject, allows for a better understanding of its activity in organizations [132].

Vocational training programs based on on-the-job learning contribute to productivity and innovation in organizations. This contribution translates into greater autonomy for workers, who require less supervision, have greater commitment and responsibility for the quality of their work, as well as greater flexibility [133].

Professional training in the context of firefighters comprises initial training for entry into the career of firefighter and firefighter officer, the necessary access training for career progression and the training of command staff, under the competence of the National Emergency and Civil Protection Authority (ANEPC) that ensures the actions considered necessary for this purpose [134]. In fact, over the last three years, the Portuguese National Fire School has provided the Firefighter Leadership Course (Advanced Module destinated to Commanding Officers (Commanders, 2nd Commanders and Deputy Commanders)). Since leadership competence development is a recent area of study in fire services in Portugal, and because there is no specific model to this area of expertise, it has adopted Roucos's Leadership Competences Management Model from the military context to serve as a support to the training program. For this reason, Rouco's Leadership Competences Management Model, presented in Table 1, was also used for support in this study.

The professional firefighter profile was published in May 2018, in the Labor and Employment Bulletin, and it contains the organization of the training reference, with the respective training units in the technological aspect, to obtain the competences to perform the role of firefighter [135]. This reference for technological training, being transversal to apprenticeship courses, professional courses, modular training and education and training for adults, recommends $850 \mathrm{~h}$ in pre-defined short-term training units (STTU) and $150 \mathrm{~h}$ obtained from other STTU. For the last $150 \mathrm{~h}$, among 59 possible STTUs, there are three STTUs of $25 \mathrm{~h}$ each about leadership, in the activity of firefighters for initiation, development, and advanced levels.

In the legal diplomas, created for regulation of admission and access to the firefighter career, we see a separation between the professional firefighter career and the volunteer firefighter career, with a particular focus on its duration and content [136,137].

Within the scope of leadership training, we can see that in the regulation aimed at professional firefighters, only $6 \mathrm{~h}$ are considered on the theme of leadership for admission, followed by three levels for accessing higher ranks in the firefighter's [137] career. It is also allowed to carry out training actions on leadership integrated in the training plan of the Municipality of Lisbon, through the Department of Development and Training (DDF) of 
the Directorate of Human Resources of Lisbon Municipality (DMRH/CML), which is open to employees from other municipalities [138].

The empowerment of the individual through education and vocational training programs implies considering the dimensions of the approach focused on the development of people and the priorities of organizations [139]. Within leadership development, it is also necessary to consider the effects that training has on this topic and what effect time has on developed competences, which may vary according to the type of competence and existing training, in terms of impact in the organization, as in the individual [140].

This research aims to identify the role of the Initial Training Course for Professional Firefighters (ITCPF) in the improvement of the proficiency level of leadership competences in firefighter trainees. To guarantee the coherence and orientation of this investigation, the following starting question was established: does the Initial Training course for Professional Firefighters contribute to the improvement in the proficiency level of leadership competences?

Based on the literature review and the starting question, we designed the conceptual model presented in Figure 2.

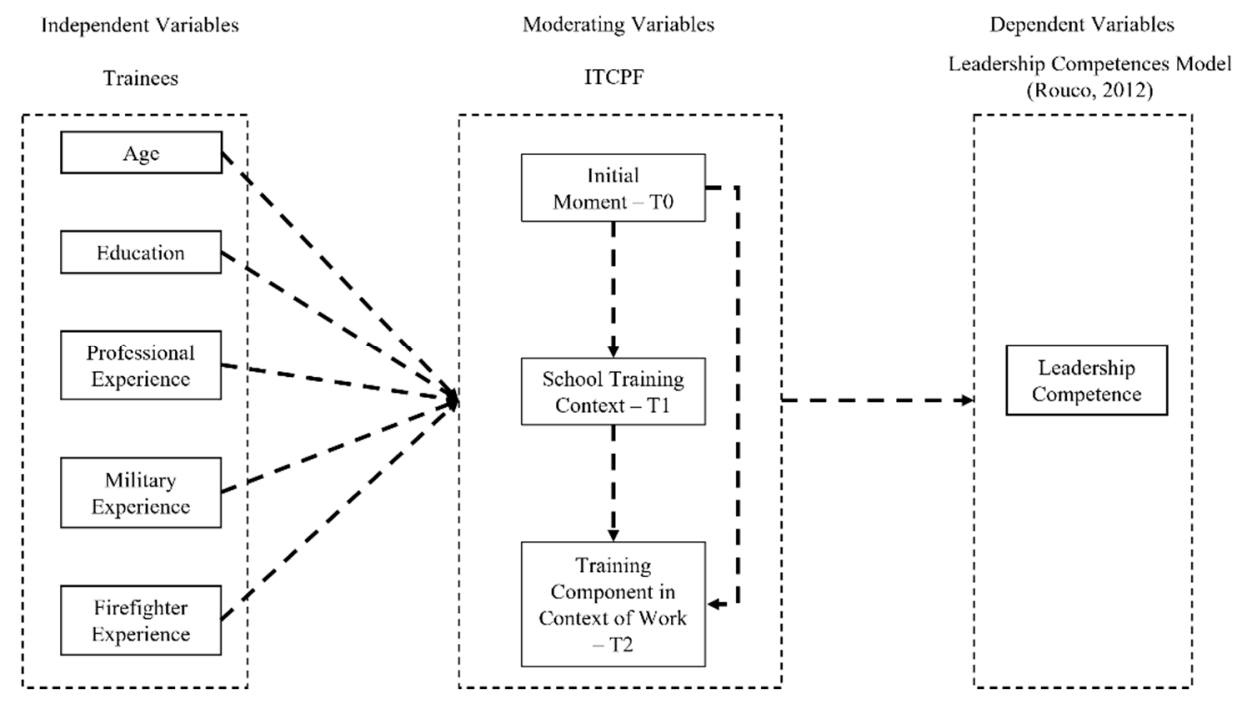

Figure 2. Conceptual model of the investigation.

Considering the object of study in this investigation, the variables under study and in accordance with the conceptual model, we formulated the following hypotheses:

(A) Because training is an important aspect for leadership competence improvement, and with time, the impact of this improvement actually regresses to residual levels [141]:

Hypothesis 1 (H1). There are significant differences in the proficiency level of leadership competences between the beginning of the course and school training.

Hypothesis 2 (H2). There are significant differences in the proficiency level of leadership competences between school education and on-the-job training.

Hypothesis 3 (H3). There are significant differences in the proficiency level of leadership competences between the beginning of the course and on-the-job training.

(B) Amongst young individuals, there are findings that support results-oriented leadership, while older individuals tend to be team-oriented players [57] and for that reason, the following hypothesis was formulated:

Hypothesis 4 (H4). There is an age group of interns that present proficiency levels of leadership competences that are significantly different from the other.

(C) The impact of formal education on leadership competences is described to enhance attributes such as integrity and interpersonal and team-oriented behaviors [65]. For this reason, the following hypothesis was formulated: 
Hypothesis 5 (H5). There is a level of education that presents proficiency levels of leadership competences that are significantly different from others.

(D) Considering that leadership outcomes may vary from the experiences that each individual has, and is not transversal throughout the career [62-64], the following hypotheses were formulated:

Hypothesis 6 (H6). Professional experience prior to entering the career significantly influences the proficiency level of leadership competences in interns.

Hypothesis 7 (H7). Military experience prior to entering the career significantly influences the proficiency level of leadership competences in interns.

Hypothesis 8 (H8). Previous experience as a firefighter significantly influences the proficiency level of leadership competences in interns.

\section{Materials and Methods}

\subsection{Course Description}

The study was conducted in the Lisbon Fire Service during the ITCPF. The course objectives are to prepare individuals to suppress fires and perform rescue and assistance to the population during all types of incidents, accidents, or calamities, whether they are from man-made events or natural phenomena. The course runs for $1800 \mathrm{~h}$ (one year), divided into six months $(910 \mathrm{~h}$ ) of school training with physical, practical, and theoretical sessions followed by another six months ( $890 \mathrm{~h}$ ) with on-the-job training (probation period).

During the School Context Training (STC) trainees are grouped in platoons and each are assigned a group of instructors. In the six months of STC trainees must comply with the following: $485 \mathrm{~h}$ of theorical sessions that include 6 major areas like fire suppression; basic technical knowledge of electricity, hydraulic, topography, communications, water supply sources, hazardous substances, personal protective equipment, engineering and construction, and vehicles and equipment; $250 \mathrm{~h}$ of practical sessions that include drills, simulations and operational maneuvers; $175 \mathrm{~h}$ of physical training sessions that include cardio fitness, swimming, upper and lower body strength and flexibility.

Within these three different sets of sessions, while within their platoon, trainees work individually at the theorical and physical sessions relying solely on their own effort. During practical sessions, trainees are submitted to drills, simulations and operational exercises as a team or teams within their own platoon. During these six months, trainees share the same barracks, washrooms, and mealtimes with their fellow trainees in their platoon.

For Training Component in Context of Work (TCCW), trainees are distributed between 11 fire stations within Lisbon Municipality. This organizational model will divide the platoon into 4 smaller teams and trainees integrate the regular shifts of $12 \mathrm{~h}$ of work with teams of senior firefighters.

Considering that this course is the main foundation of the firefighter's career and their development in terms of career progression, it is intended to identify the leadership competences with the highest proficiency levels when entering the course and verify which leadership competence levels most improve with the course.

\subsection{Research Methodology}

To obtain the objectives of the investigation, researchers conducted a case study of the ITCPF at Lisbon Fire Service because it is the only place in Portugal where it is carried out. To verify if ITCPF increases the proficiency level of leadership competences in trainees, researchers used a quantitative method through the application of a questionnaire with closed questions. For Fortin et al. [141] the quantitative method implies a systematic process of collecting data that can be observed and measured, and Sauders et al. [142] describes it as a synonym for any data collection technique, whether by questionnaire or by analyzing graphs and statistics. 
To verify the improvement of the proficiency level of leadership competences throughout the course, researchers conducted a longitudinal study with the application of the questionnaire in three different moments (T0, T1 and T2). The criteria for the questionnaire application on these three specific moments was that these provide significant change and therefore offer the possibility to verify the existence of differences in the improvement of these competences, according to the different moments of the initial training course and the existence of differences in perceived competences according to age, level of education and previous experience (professional, military and volunteer firefighter).

When assessing the proficiency level of competence at the beginning of the course, it is sought to define the starting point with which trainees enter the course and thus establish a basis for different competences and different domains.

At the end of the six months, it is intended to measure the impact that the school training phase has on the proficiency levels of leadership competence perceived by the interns, at which time they will be evaluated again and compared with the values initially collected.

Moving to an on-the-job training regime after the initial six months of school training, the proficiency levels of leadership competence perceived by the interns will be evaluated again, where it is intended to verify what effect the contact with real situations and future colleagues have in the interns and in their perception of the proficiency level of their leadership competence.

\subsection{Data Collection Instrument}

To collect data, researchers used a questionnaire with closed questions. The questionnaires aimed to collect information about certain aspects such as facts, opinions, attitudes, preferences, values, satisfaction, beliefs, motives or knowledge [143], based on great flexibility in their structure, form and means of collecting that same information. [144]. Questionnaires, as quick-to-administer instruments, require participants to respond in writing and can sometimes be completed without interviewer assistance, interference, or variability. For these reasons, they are shown to be a more convenient instrument for respondents, being the collection method most used by researchers [141,145].

The questionnaire used to collect data in this study was Rouco's Leadership Competences Management Model Questionnaire [80], consisting of two parts that focus on the sociodemographic characterization of the sample through 6 closed questions and on the assessment of the proficiency level of leadership competences, through 81 targeted items for the 27 leadership competences of the adopted model, for example "I am good at identifying problems of the team". Respondents answered the questionnaire on the proficiency level perceived by themselves about leadership competences, assigning a rating on their perception of the different competences analyzed according to their degree of agreement with the statements, based on a Likert scale of 5 items ( $1=$ strongly disagree; 5 = strongly agree).

The questionnaire was distributed in digital format during the training course, at three different times. All 81 items were mandatory. This feature allowed for the collection of 126 valid answers without any missing values.

The questionnaire was available for 5 days in each moment. Trainees were informed of the research objectives and the importance of participating, being asked to assign a personal code from the moment T0, which could be reused individually by each respondent, at different times during the training year. This feature allowed the team of researchers to match the responses throughout the course, as well as to assess the differences between the different contact moments (T0, T1 and T2).

\subsection{Sample}

The size of the sample consists of every single trainee that was admitted to the ITCPF and the response rate was total, since all trainees were asked to participate and stayed for an entire year without any drop-out from the training course. The sample is composed by 126 trainees from the ITCPF. The sample consists of 122 males and 4 females, aged between 
18 and 35 years $(n=126)$, whose level of education varies from secondary education $(n=116)$ to higher education $(n=10)$. In the sample considered, there are elements with professional experience $(n=52)$ and without professional experience $(n=74)$, with military experience $(n=47)$ and without military experience $(n=79)$ and with experience as a firefighter $(n=27)$ and without experience as a firefighter $(n=99)$.

\subsection{Statistic Methods}

For the treatment and analysis of the collected data, computer programs were used that allowed, soon after data collection, its registration in a database provided by the Google Sheet platform and which facilitated the process of transposition to a Microsoft Office Excel book 365. After working with the collected data, the existing database was transferred to the statistical treatment program IBM Statistical Package for Social Sciences (SPSS 20.0).

To enable the answer to the initial question, several techniques and tests were used, namely using descriptive statistics, from which location measures stand out, specifically those considered to be of central tendency, as they seek to characterize the value of the variable under study that occurs more frequently [146], namely arithmetic mean, median, mode and measures of dispersion of observations, namely the standard deviation of the responses obtained from the trainees during the different moments of the course. Graphs and tables were also used to support and organize information throughout the investigation.

The selection of statistical tests must consider the type of data, the population or sample and the objectives to be achieved, trying to verify whether the differences between the population values and the observed data are fortuitous [147].

In confirming or disproving the research hypotheses, the level of statistical significance was considered, as a valid procedure for verifying the differences between the formulated hypotheses and the data obtained from the study population and whose measure is the $\rho$-value. The definition of the level of significance allows for establishing the maximum probability of rejecting the null hypotheses when they are true, a situation called type I error [147]. For Fisher, the $\rho$-value of 0.05 is that which is necessary to decide whether a given effect on the population is in fact real and not the result of chance. Thus, the lower the value of $\rho$, the stronger the evidence against the null hypothesis, however, the interpretation of $\rho$-significant value must be at the discretion of the investigator and the type of study in question [148]. The $\rho$-value $\leq 0.05$ was defined for this study as the limit to accept the alternative hypothesis.

To verify the normality of the distribution, the Kolmogorov-Smirnov adherence tests were used, according to the fulfillment of the application conditions, namely the existence of a sample greater than 50 individuals, or the Shapiro-Wilk test when the sample is equal or less than this value.

The tests used were the Student t-test to compare means in paired samples or independent samples considering, when possible, the application of the central limit theorem (CLT). Parametric tests, and in particular the Student t-test, are more robust and more likely to detect a real effect on the population [146].

In cases where normality was not verified and CLT could not be applied, non-parametric tests were an option, namely the Mann-Whitney test for two independent samples.

To test the confirmation or disavowal of $\mathrm{H} 1, \mathrm{H} 2$ and $\mathrm{H} 3$, the Student parametric t-test for paired samples was used, considering that data from the same population were obtained at different times of training.

To test the confirmation or disavowal of H4, H6 and H7, the Student parametric t-test for two independent samples was used.

To confirm or disprove H5and H8, the Mann-Whitney test for two independent samples was used due to non-compliance with the normality criterion.

For this reason, results of the tests performed will be presented in tables accordingly with the type of test and variables considered. 


\section{Results}

The questionnaire is validated for the Portuguese population and presented a Cronbach's alpha between 0.8 and 0.9 for the 27 competences studied, which represents good internal consistency [149].

\subsection{Descriptive Analysis}

In this section, two types of results will be presented, resulting from the descriptive analysis of the variables and the inferential analysis of the collected data. The descriptive analysis shown in Figure 3 indicates the perception of the proficiency level in each of the competences, from the perspective of the trainees, showing which was higher throughout the ITCPF.

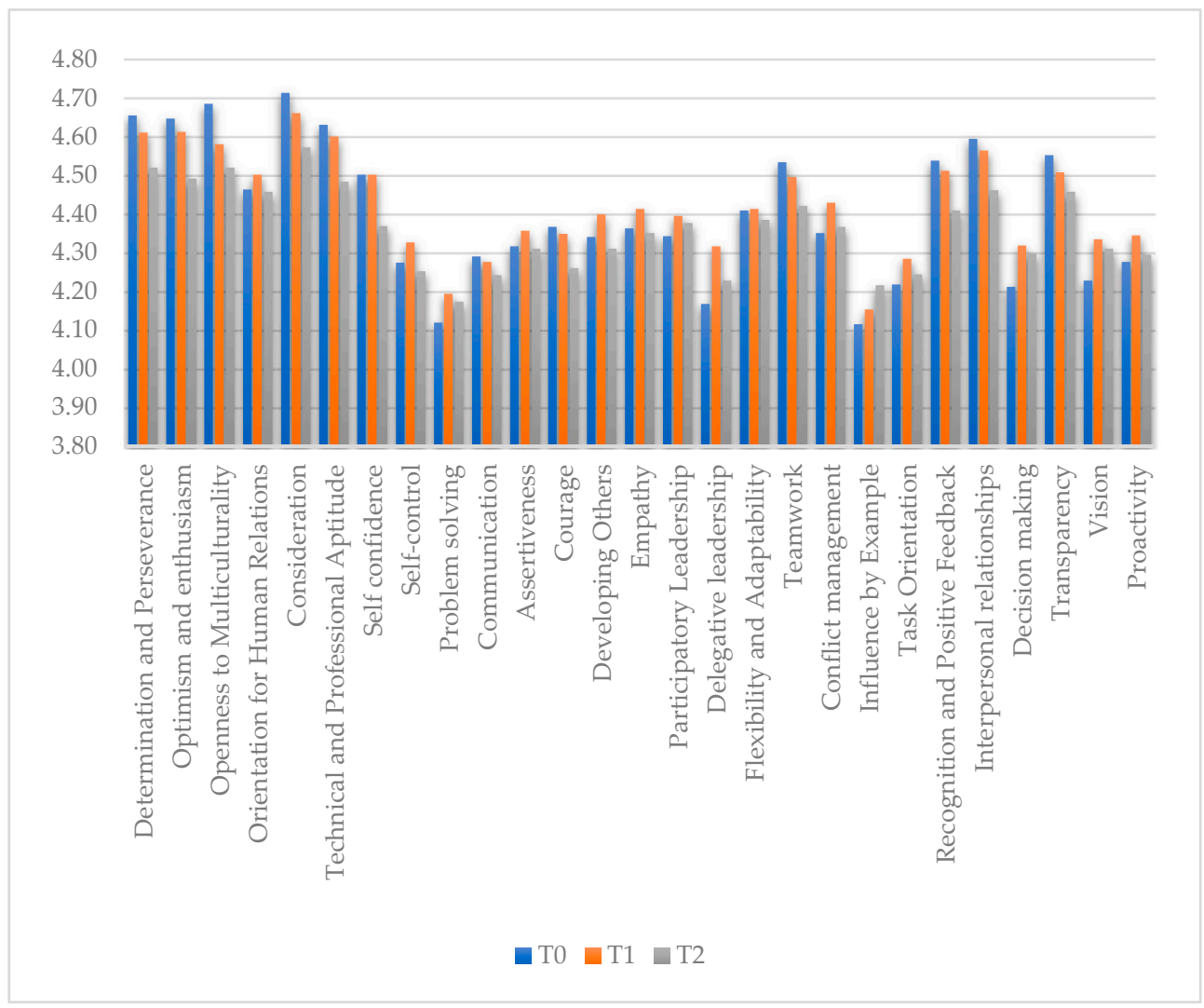

Figure 3. Improvement in leadership competences.

The five leadership competences perceived to have the highest proficiency levels throughout the course include consideration $(\bar{X}=4.57, S=0.49)$, determination and perseverance $(\bar{X}=4.52, S=0.49)$, openness to multiculturalism $(\bar{X}=4.52, S=0.49)$, optimism and enthusiasm $(\bar{X}=4.49, S=0.49)$, and technical and professional aptitude $(\bar{X}=4.48, S=0.48)$.

Based on age, trainees over 25 include the transparency competence $(\bar{X}=4.54, S=0.56)$, at the expense of optimism and enthusiasm.

Looking at the level of education as a perspective, the graduates with higher education levels included, as more proficient, the competences orientation for human relations $(\bar{X}=4.90, S=0.16)$ and interpersonal relationships $(\bar{X}=4.73, S=0.41)$, to the detriment of technical and professional aptitude.

Regarding previous experience, the trainees, in addition to generally perceiving the same competences, indicated transparency as one of the most proficient, specifically in individuals without professional experience $(\bar{X}=4.47, S=0.56)$, in individuals with military experience $(\bar{X}=4.53, S=0.57)$ and individuals with experience as a firefighter $(\bar{X}=4.48$, $S=0.55)$. 


\subsection{Comparison between Different Moments of the Course}

Regarding the improvement of the proficiency level of leadership competences, the Student $t$-test for paired samples was used, which assumes that the dependent variables are of the scalar type and with normal distribution. Despite fulfilling the first, the sample did not present a normal distribution at times T0, $\mathrm{T} 1$ and $\mathrm{T} 2\left(\mathrm{KS}_{(126)}=>0.15<035, \rho=0.00\right)$, but considering the central limit theorem, it is assumed that the sample is robust for the application of parametric tests [146].

It is verified that the results obtained between the different moments of the course show significant differences in some competences, according to Table 3.

Table 3. Student t-tests for paired samples at T0, T1 and T2.

\begin{tabular}{|c|c|c|c|c|c|c|c|c|c|}
\hline \multirow[t]{2}{*}{ Period } & \multirow[t]{2}{*}{ Competence } & \multirow[t]{2}{*}{$\bar{X}$} & \multirow[t]{2}{*}{$S$} & \multirow{2}{*}{$\begin{array}{l}\text { Standard } \\
\text { Error } \\
\text { Mean }\end{array}$} & \multicolumn{2}{|c|}{$\begin{array}{l}\text { 95\% Confidence } \\
\text { Interval of the } \\
\text { Difference }\end{array}$} & \multirow[t]{2}{*}{$\mathbf{t}$} & \multirow[t]{2}{*}{ df } & \multirow[t]{2}{*}{ Sig(2 Tailed) } \\
\hline & & & & & Lower & Upper & & & \\
\hline T0-T1 & Delegative leadership & -0.15 & 0.62 & 0.06 & -0.26 & -0.04 & -2.68 & 125 & 0.01 \\
\hline T1-T2 & Determination and perseverance & 0.09 & 0.46 & 0.04 & 0.01 & 0.17 & 2.21 & 125 & 0.03 \\
\hline $\mathrm{T} 1-\mathrm{T} 2$ & Optimism and enthusiasm & 0.12 & 0.47 & 0.04 & 0.04 & 0.20 & 2.93 & 125 & 0.00 \\
\hline $\mathrm{T} 1-\mathrm{T} 2$ & Technical and professional aptitude & 0.12 & 0.43 & 0.04 & 0.04 & 0.19 & 3.05 & 125 & 0.00 \\
\hline $\mathrm{T} 1-\mathrm{T} 2$ & Self confidence & 0.13 & 0.45 & 0.04 & 0.05 & 0.21 & 3.31 & 125 & 0.00 \\
\hline $\mathrm{T} 1-\mathrm{T} 2$ & Recognition and positive feedback & 0.10 & 0.51 & 0.05 & 0.01 & 0.19 & 2.27 & 125 & 0.02 \\
\hline $\mathrm{T} 1-\mathrm{T} 2$ & Interpersonal relationships & 0.10 & 0.49 & 0.04 & 0.02 & 0.19 & 2.34 & 125 & 0.02 \\
\hline T0-T2 & Determination and perseverance & 0.13 & 0.53 & 0.05 & 0.04 & 0.23 & 2.87 & 125 & 0.01 \\
\hline T0-T2 & Optimism and enthusiasm & 0.16 & 0.53 & 0.05 & 0.06 & 0.25 & 3.32 & 125 & 0.00 \\
\hline T0-T2 & Openness to multiculturality & 0.16 & 0.59 & 0.05 & 0.06 & 0.27 & 3.11 & 125 & 0.00 \\
\hline T0-T2 & Consideration & 0.14 & 0.56 & 0.05 & 0.04 & 0.24 & 2.84 & 125 & 0.01 \\
\hline T0-T2 & Technical and professional aptitude & 0.15 & 0.49 & 0.04 & 0.06 & 0.23 & 3.41 & 125 & 0.00 \\
\hline T0-T2 & Self confidence & 0.13 & 0.54 & 0.05 & 0.04 & 0.23 & 2.77 & 125 & 0.01 \\
\hline T0-T2 & Courage & 0.11 & 0.60 & 0.05 & 0.00 & 0.21 & 1.98 & 125 & 0.05 \\
\hline T0-T2 & Teamwork & 0.11 & 0.60 & 0.05 & 0.01 & 0.22 & 2.08 & 125 & 0.04 \\
\hline T0-T2 & Recognition and positive feedback & 0.13 & 0.56 & 0.05 & 0.03 & 0.23 & 2.61 & 125 & 0.01 \\
\hline T0-T2 & Interpersonal relationships & 0.13 & 0.56 & 0.05 & 0.03 & 0.23 & 2.66 & 125 & 0.01 \\
\hline
\end{tabular}

In accordance with age, professional and military experience, results are showed in Table 4. Based on age, at the beginning of the course, there are statistically significant differences in problem solving $(\mathrm{t}(124)=-2.15 ; \rho=0.03)$ and influence by example $(t(124)=-2.04 ; \rho=0.04)$, while at the end of school education and on-the-job training, there are no statistically significant differences between the age groups.

Table 4. Student $\mathrm{t}$-tests for independent samples based on age, professional and military experience.

\begin{tabular}{|c|c|c|c|c|c|c|c|c|c|}
\hline \multirow[t]{2}{*}{ Variable } & \multirow[t]{2}{*}{ Moment } & \multirow[t]{2}{*}{ Competence } & \multirow[t]{2}{*}{$\mathbf{t}$} & \multirow[t]{2}{*}{ df } & & \multirow{2}{*}{$\begin{array}{c}\text { Mean } \\
\text { Differ- } \\
\text { ence }\end{array}$} & \multirow{2}{*}{$\begin{array}{c}\text { Std. Error } \\
\text { Differ- } \\
\text { ence }\end{array}$} & \multicolumn{2}{|c|}{$\begin{array}{c}95 \% \text { Confidence } \\
\text { Interval of Difference }\end{array}$} \\
\hline & & & & & & & & Lower & Upper \\
\hline \multirow{2}{*}{ Age } & \multirow{2}{*}{ T0 } & Problem solving & -2.15 & 124 & 0.03 & -0.21 & 0.10 & -0.40 & -0.02 \\
\hline & & Influence by example & -2.04 & 124 & 0.04 & -0.21 & 0.10 & -0.41 & -0.01 \\
\hline \multirow{3}{*}{$\begin{array}{l}\text { Professional } \\
\text { experience }\end{array}$} & \multirow{2}{*}{ T0 } & Communication & -2.91 & 124 & 0.00 & -0.26 & 0.09 & -0.43 & -0.08 \\
\hline & & $\begin{array}{l}\text { Interpersonal } \\
\text { relationship }\end{array}$ & -1.98 & 124 & 0.05 & -0.15 & 0.08 & -0.31 & 0.00 \\
\hline & $\mathrm{T} 2$ & Self-confidence & -2.01 & 124 & 0.05 & -0.19 & 0.09 & -0.37 & 0.00 \\
\hline \multirow{3}{*}{$\begin{array}{c}\text { Military } \\
\text { experience }\end{array}$} & T0 & Influence by example & -2.00 & 124 & 0.05 & -0.21 & 0.11 & -0.42 & 0.00 \\
\hline & 10 & Decision making & -2.13 & 124 & 0.03 & -0.20 & 0.09 & -0.39 & -0.01 \\
\hline & $\mathrm{T} 1$ & Self-control & -1.98 & 124 & 0.05 & -0.21 & 0.11 & -0.42 & 0.00 \\
\hline
\end{tabular}


We verified that, at the beginning of the course, there are significant differences in the competences communication $(\mathrm{t}(124)=-2.91 ; \rho<0.001)$ and interpersonal relationships $(\mathrm{t}(124)=-1.98 ; \rho \leq 0.05)$, between interns without professional experience and interns with professional experience. In school education, there are no statistically significant differences $(\rho$-value $>0.05)$ in the proficiency levels of leadership competences in relation to professional experience. In training in the work context, there is only a statistically significant difference in self-confidence $(\mathrm{t}(124)=-2.01 ; \rho \leq 0.05)$.

Regarding military experience, at the beginning of the course, there are statistically significant differences in influence by example $(\mathrm{t}(124)=-2.00 ; \rho=0.05)$ and decision making $(t(124)=-2.13 ; \rho=0.03)$. In school education, the statistically significant difference occurs in self-control $(\mathrm{t}(124)=-1.98 ; \rho=0.05)$. In training, in the work context, there are no statistically significant differences $(\rho>0.05)$ between the proficiency levels of leadership competences of interns without military experience and interns with experience. Table 5.

Considering education and previous firefighting experience, results are showed in

Table 5. Mann-Whitney tests for independent samples based on education and firefighter experience.

\begin{tabular}{|c|c|c|c|c|}
\hline Variable & Moment & Competence & $\mathbf{U}$ & Sig(2 Tailed) \\
\hline \multirow{13}{*}{ Education } & \multirow{4}{*}{ T0 } & Flexibility and adaptability & 365.00 & 0.05 \\
\hline & & $\begin{array}{l}\text { Recognition and } \\
\text { positive feedback }\end{array}$ & 366.50 & 0.04 \\
\hline & & Interpersonal relationships & 355.00 & 0.03 \\
\hline & & Proactivity & 362.50 & 0.04 \\
\hline & \multirow{3}{*}{$\mathrm{T} 1$} & Openness to multiculturalism & 376.50 & 0.05 \\
\hline & & Orientation to human relations & 336.00 & 0.02 \\
\hline & & Delegative leadership & 362.00 & 0.04 \\
\hline & \multirow{6}{*}{$\mathrm{T} 2$} & Optimism and enthusiasm & 354.00 & 0.03 \\
\hline & & Orientation to human relations & 221.50 & 0.00 \\
\hline & & Communication & 309.00 & 0.01 \\
\hline & & Delegative leadership & 349.00 & 0.03 \\
\hline & & Conflict management & 353.50 & 0.03 \\
\hline & & Influence by example & 338.00 & 0.02 \\
\hline \multirow{2}{*}{$\begin{array}{l}\text { Firefighter } \\
\text { experience }\end{array}$} & T0 & Courage & 1004.50 & 0.04 \\
\hline & $\mathrm{T} 1$ & Problem solving & 978.00 & 0.03 \\
\hline
\end{tabular}

The results indicate that, at the beginning of the course, interns with secondary level education have significantly different levels of agreement than those with a higher level of education, in flexibility and adaptability ( $\mathrm{U}=365.00 ; \rho \leq 0.05)$; recognition and positive feedback $(\mathrm{U}=366.50 ; \rho \leq 0.05)$; interpersonal relationships $(\mathrm{U}=355.00 ; \rho \leq 0.05)$ and proactivity $(\mathrm{U}=362.50 ; \rho \leq 0.05)$. In school education, statistically significant differences are found in openness to multiculturalism $(U=376.50 ; \rho \leq 0.05)$; orientation for human relations $(\mathrm{U}=336.00 ; \rho \leq 0.05)$ and delegative leadership $(\mathrm{U}=362.00 ; \rho \leq 0.05)$, while in training, in the work context, the competences that present statistically significant differences are optimism and enthusiasm ( $U=354.00 ; \rho \leq 0.05)$, orientation to human relations $(\mathrm{U}=221.50 ; \rho \leq 0.05)$, communication $(\mathrm{U}=309,00 ; \rho \leq 0.05)$, delegative leadership $(\mathrm{U}=349.00 ; \rho \leq 0.05)$, conflict management $(\mathrm{U}=353.50 ; \rho \leq 0.05)$ and influence by example $(\mathrm{U}=338.00 ; \rho \leq 0.05)$.

Regarding previous experience as a firefighter, there is a statistically significant difference at the beginning of the course between interns without experience and interns with experience, namely in courage $(\mathrm{U}=1004.50 ; \rho \leq 0.05)$, while in school education there is a significant difference in problem solving $(\mathrm{U}=978.00 ; \rho \leq 0.05)$. There are no statistically significant differences in the proficiency level of leadership competences between interns with and without experience as a firefighter during on-the-job training. 


\section{Discussion}

This study is a pioneer in the identification of the proficiency level of leadership competences in the ITCPF, and there are no other results from other authors; however, there will be a discussion focusing on the structure of the course and contents taught. This approach will allow for the conducting of changes at the course itself, towards leadership competences development. The experience and knowledge of sixteen years of firefighting of one of the authors, and the experience in teaching and education in fire service and military context of both authors, will be used to discuss the results from their perspective.

\subsection{Proficiency Levels of Leadesrship Competences in ITCPF}

The five leadership competences that hold the highest proficiency level throughout the course are consideration, determination and perseverance, openness to multiculturalism, optimism and enthusiasm, and technical and professional aptitude. These results indicate that trainees give importance to a certain amount of mutual trust and respect for others, while understanding their needs and expectations. They also valorise focusing on their objectives in the face of adversity, keeping a positive attitude while aware of the necessity of maintaining the adequate technical and professional capacity [80]. The fact that the trainees are faced with the challenges presented by the course can explain why the most perceived proficiency level of leadership competences are from the personal domain. By grouping the trainees into platoons, it provides them the opportunity of experiencing the different cultures, beliefs and values which may cause the competences of the social domain to be enhanced. Finally, the fact that firefighting is prone to danger, complexity and uncertainty may explain why competences of the functional domain are also perceived as highly proficient $[36,64,75,79]$.

\subsection{Impact of STC and TCCW on Proficiency Levels of Leadership}

The results obtained indicate that STC presents higher proficiency levels in consideration, where interns develop trust and respect for the ideas, needs and expectations of others $[75,80]$; in determination and perseverance, where they seek to achieve defined goals and do not give up in the face of effort [75,76]; in optimism and enthusiasm when facing challenges, with a spirit of sacrifice and transmitting to others the enthusiasm to achieve the goals [15,79]; technical and professional aptitude, by maintaining and updating the competences and knowledge necessary to perform the tasks [55,80], and openness to multiculturalism, working with various people and maintaining respect for the different beliefs, values and cultural traditions of the others individuals [52,80].

During STC, it appears that there is a significant difference in the competence of delegative leadership, which reflects a higher perception of this competence at the end of the school period than indicated at the beginning of the course. Despite the most perceived proficiency levels of leadership competences being from the personal and technical domains, differences were also verified, although not significant, in the competences of decision making, problem solving, vision and conflict management. This improvement is particularly relevant because these skills are associated with social, organizational and functional domains, and may be explained by the number of practical simulations and drills during this period of training, which place trainees under stress and make them dependable upon each other; this leads to trainees sharing their experiences among the group and establishing a sense of belonging.

The analysis results indicate that between the beginning of the course and school training, there are significantly high differences in the proficiency levels of the delegative leadership competence, through the development of union and mutual trust [12,76]. It can be said that school training has higher levels of agreement in the improvement of 15 leadership competences, to the detriment of 11 that have lower values than those recorded at the beginning of the course. Based on these results, $\mathrm{H} 1$ is confirmed.

In terms of the TCCW, the competences with the highest proficiency level are consideration, determination and perseverance, followed by openness to multiculturalism, 
optimism and enthusiasm, and technical and professional aptitude. In this context, on-thejob training decreased the proficiency level of 26 leadership competences when compared to the results obtained during STC, which may be related to the fact that platoons are distributed in four smaller teams that are integrated in senior firefighter teams [75,80].

During the on-the-job training period, influence by example is the only competence in which there is a positive improvement, although not statistically significant, which can be explained by the hierarchical structure of the fire service and the constant presence of a senior firefighter in each team, assisted by the instructors from the STC period.

Apart from technical and professional aptitude, all the competences whose difference is statistically significant belong to either the personal or social domain of competence and show a decrease in the perceived proficiency level compared to the previous period. The decrease in the proficiency level of these leadership competences may be explained by the fact that trainees are separated from their previous group, in a different environment, and starting new relationships with their actual team, which is in line with other studies related to the effect of time on leadership development [141]. Based on these results, H2 is confirmed.

When comparing the initial and final moments of the course (T0-T3), there are ten competences with statistically significant differences, but with a decrease between the two moments considered (T1-T2).

When observing the proficiency level of leadership competences that have increased since the initial moment (T0), all competences belong to the cognitive or social competence type, with exception for the proactive competence.

The value given to these competences throughout the initial training course for firefighters suggests that the personal and social dimensions are guidelines for the study sample [31-33,56-58,63,67,79,80].

The data also indicate that TCCW presents 18 leadership competences with lower proficiency values when compared to the initial moment of the course. During this period there are significantly high differences in the competences of determination and perseverance, optimism and enthusiasm, openness to multiculturalism, consideration, technical and professional aptitude, self-confidence, courage, teamwork, recognition and positive feedback, and interpersonal relationships at the beginning of the course, thus, reinforcing the impact of training on their development [140]. These ten competences with statistically significant differences were also those which, throughout the course, had a negative evolution and to which the competences of communication and transparency are also associated. Based on these results, $\mathrm{H} 3$ is confirmed.

\subsection{Impact of Age on the Proficiency Levels of Leadership Competences}

Regarding an age group presenting proficiency levels of leadership competences that are significantly different from the other, results indicate that trainees $\geq 25$-years-old scored significantly higher in problem solving and influence by example, but only in the initial moment.

The initial perception (T0) of the proficiency level of leadership competences in trainees $\geq 25$-years-old is higher than the other age group for all leadership competences.

However, during the STC, they only perceive higher proficiency levels of leadership competences than younger trainees in optimism and enthusiasm, professional and technical aptitude, self-control, and participative leadership. Of that previously mentioned, only self-control is higher than the initial proficiency level. During this phase, not only did their proficiency level decrease in most of the leadership competences, but also younger trainees increased theirs. During TCCW, trainees $\geq 25$-years-old perceive their proficiency level of leadership competences higher than younger trainees, with exception to consideration, self-confidence, empathy, flexibility and adaptability, and recognition and positive feedback. In all of these, and despite perceiving it as lower than younger trainees, the older trainees decreased their proficiency levels in comparison with STC levels. 
Looking at the overall effect, trainees $\geq 25$-years-old increased their proficiency levels in five competences, while younger trainees increased their proficiency level in 14 leadership competences.

One interpretation is that the STC of the ITCPF is most beneficial in increasing the proficiency level of leadership competences in younger trainees because it empowers trainees in an environment that is new to them. Another possible interpretation is that TCCW is more stimulating to older trainees than younger ones because they see themselves without the support of the group, forged during STC, and this forces individuals to reach out for their core values and competences to obtain their position within the new group (shift).

Considering the statistically significant differences observed at the initial moment (T0) and the fluctuation in the proficiency level of leadership competences throughout the ITCPF, $\mathrm{H} 4$ is partially confirmed.

\subsection{Impact of Education on the Proficiency Levels of Leadership Competences}

Regarding a level of education presenting proficiency levels of leadership competences significantly different from others, the results indicate that trainees with higher education levels perceive significantly higher proficiency levels than others at every moment of the course.

The initial perception indicates that trainees with higher education perceive higher proficiency levels in all leadership competences, and particularly in flexibility and adaptability, recognition and positive feedback, interpersonal relationships, and proactivity, dividing their focus in personal and social domains of competence.

During STC, trainees with higher education perceive higher proficiency levels in all leadership competences, except self-control, where they perceive the same proficiency level as trainees with a secondary level of education. At this phase of ITCPF, openness to multiculturalism, orientation to human relations, interpersonal relationships and delegative leadership are the competences that significantly differ from trainees with a secondary level of education. All these competences are from the social domain and are consistent with the necessity of trainees during STC, to establish their connections within their own platoon.

Once in TCCW, trainees with higher education, again, perceive higher proficiency levels in all leadership competences, except self-confidence, where again, they perceive the same proficiency level as trainees with a secondary level of education. During TCCW, optimism and enthusiasm, orientation to human relations, communication, delegative leadership, conflict management and influence by example are competences that significantly differ from trainees with a secondary level of education. Most of these competences belong to the social domain, but personal and organizational domains are also present. One interpretation of these results is that trainees need to use more than social domain competences once they integrate TCCW and a new environment is created, forcing trainees, specifically the ones with higher education, to continue increasing their proficiency level of leadership competences [12,13]. Therefore, H5 is confirmed.

\subsection{Impact of Professional Experience on the Proficiency Levels of Leadership Competences}

Regarding professional experience prior to entering the career to have significantly influenced the proficiency level of leadership competences, the results show that trainees with previous professional experience scored higher in communication and interpersonal relationships when entering the course and are more self-confident at the end of the course than others. The initial perception indicates that trainees with professional experience perceive higher proficiency levels in all leadership competences and they only maintain higher proficiency levels compared with trainees that do not possess professional experience in optimism and enthusiasm, openness to multiculturality, professional and technical aptitude, self-confidence, teamwork, influence by example, interpersonal relationships and decision making during STC. Of these competences, only influence by example and decision making present an increase in their proficiency levels. During this first phase of the ITCPF, not only do trainees with professional experience decrease their proficiency levels, but trainees 
without professional experience increase their proficiency levels of leadership competences. Here, STC also provides a platform for trainees without professional experience to increase their proficiency levels, through the number of practical drills and simulations that force trainees to step up and assume leadership roles within the teams and platoon.

During TCCW, trainees with professional experience obtained higher proficiency levels in all leadership competences, except transparency, when compared with others. This is something that reflects not only the fact that trainees are divided into small teams in different fire stations but also the fact that drills and simulations are significantly reduced during TCCW.

Considering the statistically significant differences observed at the initial and final moments (T0/T2), and the fluctuation in the proficiency level of leadership competences throughout the ITCPF, H6 is partially confirmed.

\subsection{Impact of Military Experience on the Proficiency Levels of Leadership Competences}

Considering military experience prior to entering the course to have significantly influenced the proficiency level of leadership competences, the results show that trainees with military experience at the beginning of the course scored significantly higher in influence by example and decision making. They also scored significantly higher in self-control during school training but did not show significant differences in on-the-job training.

When entering the ITCPF, trainees with military experience reveal higher proficiency levels in all leadership competences, except orientation to human relations, consideration, and communication. During STC, they increase their proficiency levels in 19 leadership competences and perceive higher proficiency levels, when compared with trainees without military experience, with exception to openness to multiculturalism. This is also observed in TCCW, despite the increase during this last phase of ITCPF being residual and mostly observed in trainees without military experience.

The interpretation that can be made from these results is that military experience stands out during STC, with significant difference in self-control, because its actively requested during simulations and drills, and prolongs TCCW, but in this stage, there is a decrease in the proficiency levels of leadership competences, because trainees' range of autonomy is also decreased, along with the effects of time on leadership competences $[75,141]$. Therefore, H7 is partially confirmed.

\subsection{Impact of Firefighting Experience on the Proficiency Levels of Leadership Competences}

Regarding previous experience as a firefighter to have significantly influenced the proficiency level of leadership competence, results indicate that trainees without experience scored significantly higher at the beginning of the course in courage. During school training, they scored significantly higher in problem solving. During on-the-job training, they do not show significant differences between themselves and trainees.

During the initial moment (T0), trainees without firefighting experience perceived higher proficiency levels of leadership competences than others, with the exception of consideration, which was perceived with higher proficiency level by trainees with firefighting experience, and conflict management, in which they perceived both the same level. At the end of STC, trainees without firefighting experience perceived higher proficiency levels in all leadership competences, with the exception of interpersonal relationships. Despite this, STC allowed trainees to increase their proficiency level for 16 competences in trainees without experience and 11 in experienced trainees. This was not observed during TCCW, in which only one competence increased its proficiency level in trainees without experience, while trainees with firefighting experience increased their proficiency levels in 16 leadership competences. The effect of STC on trainees without experience is higher because simulations and drills during the first phase of the ITCPF stimulates trainees to a different reality that they are not familiarized with and without the presence of threatened lives. Another interpretation may be that trainees with experience as firefighters may consider simulations and drills a form of game, which they play without the risk of losing, 
a fact that could explain the increase in proficiency levels of leadership competences during TCCW. For this, H8 is partially confirmed.

In synthesis, education is the variable that promotes significant differences between trainees in personal, social and organizational domains of competence.

Among all the leadership competences with proficiency values lower than the initial ones, it is plausible to affirm that the ITCPF can promote the improvement of some personal and social competences in the first phase of the course, not being able to maintain this improvement during the second phase of training. This inability is also verified in competences in which improvement is observed, when considering the value obtained at the end of school education, with exception for the competence influenced by example.

\section{Conclusions}

In response to the initial question, it is concluded that the training course contributes to the improvement of the proficiency level of the following nine leadership competences: problem solving, participatory leadership, delegative leadership, conflict management, influence by example, task orientation, decision making, vision and proactivity.

On the other hand, it is also concluded that there are ten competences where there is a setback in the proficiency level, where the differences between the levels of entry into the training course are significantly higher than the levels of exit. This conclusion is of particular interest, since there has been an increase, albeit barely significant, in the proficiency level during STC and an inflection in the improvement of competences during TCCW.

Another conclusion drawn from this investigation is that the most valued competences are in the personal, social, and functional domain, but the competences that received constant improvement are mostly associated to the social, functional, and organizational domains. The course has a standardizing trend, regarding leadership competences, regardless of the characteristics of the sample but this is generally focused in social, functional, and organizational areas, leaving the personal competences at the expenses of each individual's background.

This investigation holds, as practical implications, the mapping of leadership competences in initial training courses for professional firefighters in Portugal and the contribution of this course in their improvement.

The greatest relevance for this work for Portuguese firefighters is the identification of the contribution of the initial training course, regarding leadership competences; allowing the creation of the platform necessary to identify possible areas of development in the leadership competences for career progression; adjustments in the course itself (by inducing leadership awareness in the course); alignment of the definition of terms associated with leadership that will allow a common glossary for firefighters as a whole and that will benefit the recruitment, selection, evaluation, career progression and operationalization of the decision-making process in joint operations.

The implication for the theoretical field is the proof that ITCPF did increase the proficiency level of leadership competences, based on simulations, drills and the reflexions that are made upon completing these sessions, allowing the adult trainees to analyse, dissect and assimilate the different aspects of the firefighting activity, in accordance with Kolb's experiential learning cycle [114].

The main limitations of this research were the limited literature and scientific research available, in terms of leadership competences applied to fire services in Portugal, a fact that forced an additional research effort, to obtain references abroad and from other fire services, who are often integrated into clearly different organizational structures and with very specific cultural, social, and political dimensions. Furthermore, the reduced number of female trainees did not allow us to obtain any suitable information regarding differences between male and female trainees' proficiency level of the different leadership competences.

As a future proposal, it is suggested that researchers should identify which competences are considered core to firefighters, according to the respective functional profile applicable to each category, thus, allowing the opening of new lines of research on lead- 
ership throughout the career, either through the diagnosis of the existing competence proficiency level, with the creation of a specific leadership competence management model for firefighters, or through the anticipation of the needs of their officers and commanders, prior to their ascension in the structure.

Author Contributions: Conceptualization, J.C. and C.R.; methodology, J.C. and C.R.; software, J.C. and C.R.; validation, C.R.; formal analysis, J.C. and C.R.; investigation, J.C. and C.R.; resources, J.C.; data curation, J.C.; writing-original draft preparation, J.C.; writing-review and editing, C.R.; visualization, J.C. and C.R.; supervision, J.C.; project administration, J.C.; funding acquisition, not applicable. All authors have read and agreed to the published version of the manuscript.

Funding: This research received no external funding.

Institutional Review Board Statement: Not applicable.

Informed Consent Statement: Informed consent was obtained from all subjects involved in the study.

Data Availability Statement: The data presented in this study are available on request from the corresponding author.

Acknowledgments: The authors wish to express their gratitude to Regimento de Sapadores Bombeiros of Lisbon Municipality for receiving this study and Commander Lieutenant-Colonel Eng. Tiago Lopes for allowing the conduction of this investigation.

Conflicts of Interest: The authors declare no conflict of interest.

\section{References}

1. National Wildfire Coordinating Group (NWCG). Leading in the Wildland Fire Service; National Wildfire Coordinating Group: Boise, ID, USA, 2007

2. Boyatzis, R. The Competent Manager: A Model for Effective Performance, 1st ed.; John Wiley \& Sons: New York, NY, USA, 1982.

3. Spencer, L.; Spencer, S. Competence at Work; John Wiley \& Sons: New York, NY, USA, 1993.

4. Neves, J.; Garrido, M.; Simões, E. Manual de Competências Pessoais, Interpessoais e Instrumentais, 3rd ed.; Edições Sílabo: Lisboa, Portugal, 2015.

5. Ceitil, M. Gestão e desenvolvimento de competências, 2nd ed.; Edições Sílabo: Lisboa, Portugal, 2016.

6. Davies, B.; Elllison, L. School Leadership for the 21st Century—A Competency and Knowledge Approach, 3rd ed.; Routledge: London, UK, 1999.

7. Almeida, C. Desenvolvimento de Competências de Liderança No Ensino Superior Militar; Instituto Universitário Militar: Pedrouços, Portugal, 2017.

8. Marques, L. Modelo de Gestão de Competências de Liderança Para a Guarda Nacional Republicana; Academia Militar: Lisboa, Portugal, 2013.

9. Oliveira, S. Influência da Liderança na Motivação de Colaboradores: Estudo de Caso à Associação Humanitária de Bombeiros Voluntários de Caminha; Instituto Politécnico de Viana do Castelo: Viana do Castelo, Portugal, 2017.

10. Esperança, T. Liderança em Contexto de Emergência: O Papel das Relações Líder-Membro; Universidade de Évora: Évora, Portugal, 2013.

11. Bass, B. The Bass Handbook of Leadership—Theory, Research and Managerial Aplications, 4th ed.; Free Press: New York, NY, USA, 2008.

12. Kouzes, J.; Posner, B. The Leadership Challenge, 6th ed.; John Wiley \& Sons: Hoboken, NJ, USA, 2017.

13. Kotter, J. Liderar a Mudança; Lua de Papel: Alfragide, Portugal, 2017.

14. Burns, J. Leadership; Harper \& Row: New York, NY, USA, 1978.

15. Yukl, G. Leadership in Organizations, 7th ed.; Prentiss Hall: Upper Saddle River, NJ, USA, 2010.

16. Carlyle, T. On Heroes, Hero-Worship and the Heroic in History; Cosimo: New York, NY, USA, 2009.

17. Bass, B.; Waldman, D.; Avolio, B.; Bebb, M. Transformational leadership and the falling dominoes effect. Group Organ. Manag. 1987, 12, 73-87. [CrossRef]

18. Conger, J.A.; Kanungo, R.N. Charismatic Leadership in Organizations; Sage: Thousand Oaks, CA, USA, 1998.

19. United States Department of the Army (USDA). U.S. Army Field Manual (FM 22-100); Department of the Army: Washington, DC, USA, 2006.

20. Judge, T.; Bono, J. Five-factor model of personality and transformational leadership. J. Appl. Psychol. 2000, 85, 751-765. [CrossRef]

21. Kelley, R. Praise of Followers; Harvard Business Review Case Services: Brighton, MA, USA, 1988.

22. Rego, A. Liderança nas Organizações: Teoria e Prática; Universidade de Aveiro: Aveiro, Portugal, 1997.

23. Bass, B. Leadership and Performance beyond Expectations; Free Press: New York, NY, USA, 1985.

24. House, R. Path-goal theory of leadership: Lessons, legacy, and a reformulated theory. Leadersh. Q. 1996, 7, 323-352. [CrossRef]

25. Blake, R.; Mouton, J.; Barnes, L.; Greiner, L. Breakthrough in organization development. Harv. Bus. Rev. 1964, 42, 133-155.

26. Hersey, P.; Blanchard, K.; Natemeyer, W. Situational leadership, perception, and the impact of power. Group Organ. Manag. 1979, 4, 418-428. [CrossRef]

27. Schein, V. Relationships between sex role stereotypes and requisite management characteristics among female managers. J. Appl. Psychol. 1975, 60, 340-344. [CrossRef] [PubMed] 
28. Stogdill, R. The evolution of leadership theory. Acad. Manag. Proc. 1975, 1, 4-6. [CrossRef]

29. Dobbins, G.; Platz, S. Sex differences in leadership: How real are they? Acad. Manag. Rev. 1986, 11, 118-127. [CrossRef]

30. Powell, G. Women and Men in Management, 2nd ed.; Sage: Thousand Oaks, CA, USA, 1993.

31. Eagly, A.; Johannesen-Schmidt, M. The leadership styles of women and men. J. Soc. Issues 2001, 57, 781-797. [CrossRef]

32. Eagly, A.; Johannesen-Schmidt, M.; Van Engen, M. Transformational, transactional, and laissez-faire leadership styles: A meta-analysis comparing women and men. Psychol. Bull. 2003, 129, 569-591. [CrossRef]

33. Eagly, A.; Johnson, B. Gender and leadership style: A meta-analysis. Psychol. Bull. 1990, 108, 233-256. [CrossRef]

34. Tzu, S. Zen Lessons: The Art of Leadership; Clearly, T., Ed.; Shambhala Publications: Boulder, CO, USA, 1989.

35. International Association of Fire Chiefs (IAFC). IAFC Officer Development Handbook, 2nd ed.; International Association of Fire Chiefs: Chantilly, VA, USA, 2010.

36. Carter, H. Approaches to leadership: The application of theory to the development of a fire service-specific leadership style. Int Fire Serv. J. Leadersh. Manag. 2007, 1, 28-37.

37. Donnelly, J.; Gibson, J.; Ivancevich, J. Administração: Princípios de Gestão Empresarial, 10th ed.; McGraw-Hill: Lisboa, Portugal, 2000.

38. International Association of Fire Chiefs (IAFC). Fire and emergency services in the United States. In Fourth Wingspread Conference; International Association of Fire Chiefs: Chantilly, VA, USA, 1996.

39. International Association of Fire Chiefs (IAFC). Fire service administration, education and research. In First Wingspread Conference; International Association of Fire Chiefs: Chantilly, VA, USA, 1966.

40. Staley, M. Igniting the Leader Within; Fire Engineering: Saddle Brook, NJ, USA, 1998.

41. Murphy, P.; Greenhalgh, K. Fire and Rescue Services: Leadership and Management Perspectives; Murphy, P., Greenhalgh, K., Eds.; Springer: Berlin/Heidelberg, Germany, 2018. [CrossRef]

42. Bartolo, K.; Furlonger, B. Leadership and job satisfation among aviation fire fighters in Australia. J. Manag. Psychol. 2000, 15, 87-97. [CrossRef]

43. Lamar, A. Effects of Transformational Leadership on Fire Lieutenant Development. [Walden University]. In Walden Dissertations and Doctoral Studies Collection. 2017. Available online: http:/ / search.ebscohost.com/login.aspx?direct=true\&db=psyh\&AN=20 18-00724-023\&site=ehost-live\&authtype=ip, shib\&user=s1523151 (accessed on 30 July 2021).

44. Alyn, K. Transformational leadership in the fire service. Fire House 2010, 35, 88-90.

45. Silva, M. Gestão e Práticas de Formação Numa Corporação de Bombeiros; Universidade de Lisboa: Lisboa, Portugal, 2012.

46. Smith, T.; Eldridge, F.; DeJoy, D. Safety-specific transformational and passive leadership influences on firefighter safety climate perceptions and safety behavior outcomes. Saf. Sci. 2016, 86, 92-97. [CrossRef]

47. Reis, R. Liderança Autêntica e o Engagement-Uma Perspetiva Positiva No Setor dos Bombeiros; Academia Militar: Lisboa, Portugal, 2017.

48. Carter, H. Fire Fighting Strategy and Tactics; Fire Protection Publications: Stillwater, OK, USA, 1998.

49. Coleman, R. Management of Fire Service Operations; Wadsworth Publishing Company: Belmont, CA, USA, 1978.

50. National Fire Protection Association (NFPA). Fire protection handbook. In Engineers Australia, 19th ed.; Number 7; Cote, A.E., Hall, J.R.J., Powell, P.A., Grant, C.C., Eds.; National Fire Protection Association: Quincy, MA, USA, 2003.

51. Paulsgrove, R. Fire department administration and operations. In Fire Protection Handbook, 19th ed.; Cote, A.E., Ed.; National Fire Protection Association: Quincy, MA, USA, 2003.

52. Armstrong, M. Leadership Development for the Fire Service; Royal Roads University: Victoria, BC, Canada, 2004.

53. Beaton, R.; Johnson, L.; Infield, S.; Ollis, T. Outcomes of a leadership intervention for a metropolitan fire department. Psychol. Rep. 2001, 88, 1049-1066. [CrossRef]

54. Steputat, L. Identifying Leadership Criteria in the Fire Service; Lewiston Fire Department: Lewiston, ID, USA, 2010.

55. Useem, M.; Cook, J.; Sutton, L. Developing leaders for decision making under stress: Wildland firefighters in the South Canyon Fire and its aftermath. Acad. Manag. Learn. Educ. 2011, 4, 461-485. [CrossRef]

56. Gilbert, G.; Collins, R.; Brenner, R. Age and leadership effectiveness: From the perceptions of the follower. Hum. Resour. Manag. 1990, 29, 187-196. [CrossRef]

57. Kabacoff, R.; Stoffey, R. Age differences in organisational leadership. In Proceedings of the 16th Annual Conference of the Society for Industrial and Organisational Psychology; Society for industrial and Organisational Psychology: San Diego, CA, USA, 2001.

58. Korac-Kakabadse, A.; Korac-Kakabadse, N.; Myers, A. Demographics and leadership philosophy: Exploring gender differences. J. Manag. Dev. 1998, 17, 5. [CrossRef]

59. Oshagbemi, T. Age influences on the leadership styles and behaviour of managers. Empl. Relat. 2004, 26, 14-29. [CrossRef]

60. Brunacini, A. Fire command, 2nd ed.; National Fire Protection Association: Quincy, MA, USA, 2002.

61. Hamm, R. Leadership in the Fire Service; International Fire Service Training Association: Stillwater, OK, USA, 1990.

62. Huston, R. Leadership Skills for New Supervisors in the South Euclid Fire Department; South Euclid Fire Department: South Euclid, OH, USA, 2009.

63. Mumford, M.; Marks, M.; Connelly, M.; Zaccaro, S.; Reiter-Palmon, R. Development of leadership skills: Experience and timing. Leadersh. Q. 2000, 11, 87-114. [CrossRef]

64. United States Army (US Army). Army Leadership Competent, Confident, and Agile FM 6-22; Department of the Army: Washington, DC, USA, 2006.

65. Green, M.; Chavez, E.; Lopez, D.; Gonzalez, F. The impact of education, gender, age and leadership experience on preferences in leadership. J. Bus. Leadersh. 2011, 7, 102-115. 
66. Kearney, E.; Gebert, D. Managing diversity and enhancing team outcomes: The promise of transformational leadership. J. Appl. Psychol. 2009, 94, 77-89. [CrossRef] [PubMed]

67. Reeves, D.; Culbreth, J.; Greene, A. Effect of sex, age, and education level on the supervisory styles of substance abuse counselor supervisors. J. Alcohol Drug Educ. 1997, 43, 76-86. Available online: https://www.proquest.com/scholarly-journals/effect-sexage-education-level-on-supervisory/docview /217435289/se-2?accountid=192066 (accessed on 5 August 2021).

68. Stout-Stewart, S. Female community-college presidents: Effective leadership patterns and behaviors. Community Coll. J. Res. Pract. 2005, 29, 303-315. [CrossRef]

69. Xirasagar, S.; Samuels, M.; Curtin, T. Management training of physician executives, their leadership style, and care management performance: An empirical study. Am. J. Manag. Care 2006, 12, 101-108.

70. Turner, N.; Barling, J.; Epitropaki, O.; Butcher, V.; Milner, C. Transformational leadership and moral reasoning. J. Appl. Psychol. 2002, 87, 304-311. [CrossRef]

71. Buttenschon, M. Reflective Insights from Today's Fireservice Leaders: A Narrative Inquiry to Inform the Next Generation's Leadership Development; Northeastern University: Boston, MA, USA, 2016. [CrossRef]

72. Kupietz, K. To change the world or to rule it: Applying transformational leadership theory to the american fire service. Int. Fire Serv. J. Leadersh. Manag. 2010, 4, 23-29.

73. Howell, J. Substitutes for leadership: Their meaning and measurement-an historical assessment. Leadersh. Q. 1997, 8, 113-116. [CrossRef]

74. Kerr, S.; Jermier, J. Substitutes for leadership: Their meaning and measurement. Organ. Behav. Hum. Perform. 1978, 22, 375-403. [CrossRef]

75. Favreau, D. Fire Service Management; Fire Engineering: Fair Lawn, NJ, USA, 1973.

76. Nash, B. Leadership \& Development in the Fire and Rescue Service; Office of the Deputy Prime Minister: London, UK, 2005.

77. Clark, W. Firefighting Principles \& Practices, 2nd ed.; Fire Engineering Books \& Videos: Tulsa, OK, USA, 1991.

78. Lopes, B. Office management and workflow. In The Fire Chief's Handbook, 6th ed.; Em, R., Barr, C., Eversole, J.M., Eds.; Penwell Corporation: Tulsa, OK, USA, 2003; pp. 13-40.

79. Vieira, B. Liderança Militar; Academia Militar: Lisboa, Portugal, 2002.

80. Rouco, J. Modelos de Gestão de Desenvolvimento de Competências de Liderança em Contexto Militar; Universidade Lusíada de Lisboa: Lisboa, Portugal, 2012.

81. Gregório, J. Caracterização das Competências e Estilos de Liderança: Estudo de Caso Sobre Uma Sociedade de Advogados Portuguesa; Academia Militar: Lisboa, Portugal, 2019.

82. Loureiro, N. O Combate em Áreas Edificadas e a Sua Implicação no Desenvolvimento de Competências de Comando e Liderança; Academia Militar: Lisboa, Portugal, 2014.

83. Seixas, S. Características e Competências de Liderança dos Cargos de Chefia dos Oficiais de Administração da Guarda, Para a Motivação dos Colaboradores: Caso dos Chefes de Divisão; Academia Militar: Lisboa, Portugal, 2012.

84. Oliveira, F.; Rouco, J.; Gladkikh, T. Riding as a way of developing soft skills in higher education. Sci. J. Proelium 2016, VII, 271-286.

85. Pedler, M.; Burgoyne, J.; Boydell, T. The Learning Company, a Strategy for Sustainable Development, 2nd ed.; McGraw-Hill: New York, NY, USA, 1997.

86. Cyert, R.; March, J. Behavioral Theory of the Firm, 2nd ed.; John Wiley \& Sons: Hoboken, NJ, USA, 1992.

87. Fernandes, A. A Tipologia da Aprendizagem Organizacional; Livros Horizonte: Lisboa, Portugal, 2005.

88. Hedberg, B. How organizations learn and unlearn. In Handbook of Organizational Design; Nystrom, P.C., Starbuck, W.H., Eds.; Oxford University Press: Oxford, UK, 1981.

89. Shrivastava, P. A typology of organizational learning systems. J. Manag. Stud. 1983, 20, 7-28. [CrossRef]

90. Lopes, A.; Picado, L. Concepção e Gestão da Formação Profissional Contínua: Da Qualificação Individual à Aprendizagem Organizacional; Edições Pedago: Ramada, Portugal, 2010.

91. Skinner, B. Cognitive science and behaviourism. Br. J. Psychol. 1985, 76, 291-301. [CrossRef] [PubMed]

92. Pavlov, I. A psicologia e a psicopatologia experimentais nos animais. In Reflexos condicionados, Inibição e Outros Textos; Estampa: Lisboa, Portugal, 1971.

93. Thorndike, E. Animal Intelligence: Experimental Studies; The Macmillan Company: New York, NY, USA, 1911.

94. Watson, J. Behaviorism; The People's Institute Publishing Company: New York, NY, USA, 1924.

95. Gagné, R. The Conditions of Learning; Holt, Rinehart \& Wiston: New York, NY, USA, 1970.

96. Kohler, W. Kurt Koffka 1886-1941. Psychol. Rev. 1942, 49, 97-101. [CrossRef]

97. Kohler, W. Gestalt psychology. Psychol. Forsch. 1967, 31, 18-30. [CrossRef]

98. Luchins, A.; Luchins, E. Max Wertheimer: 1919-1929. Gestalt. Theory 1986, 8, 4-30.

99. Bandura, A. Social Learning Theory; Prentice-Hall: Hoboken, NJ, USA, 1977.

100. Cherrington, D. Organizational Behavior: The Management of Individual and Organizational Performance, 2nd ed.; Allyn \& Bacon: Boston, MA, USA, 1994.

101. Lewin, K. Defining the «field at a given time». Psychol. Rev. 1943, 50, 292-310. [CrossRef]

102. Lewin, K. Action research and minority problems. J. Soc. Issues 1946, 2, 34-46. [CrossRef]

103. Piaget, J.; Inhelder, B. The Growth of Logical Thinking: From Childhood to Adolescence; Basic Books: New York, NY, USA, 1958.

104. Tavares, J.; Alarcão, I. Psicologia do Desenvolvimento e da Aprendizagem; Edições Almedina: Lisboa, Portugal, 2002. 
105. Maturana, H.; Varela, F. The Tree of Knowledge; Shambhala Publications: Boulder, CO, USA, 1987.

106. Bateson, G. Steps to an Ecology of Mind; Jason Aronson Inc.: Lanham, MD, USA, 1987.

107. Bertalanffy, L. General System Theory; George Braziller: New York, NY, USA, 1968.

108. Foerster, H. Understanding Understanding: Essays on Cybernetics and Cognition; Springer: Berlin/Heidelberg, Germany, 2002.

109. Oliveira, C. A Educação Como Processo Auto-Organizativo; Instituto Piaget: Lisboa, Portugal, 1999.

110. Cambridge Institute for Sustainability Leadership (CISL). Global Definitions of Leadership and Theories of Leadership Development: Literature Review; Cambridge Institute for Sustainability Leadership: Cambridge, UK, 2019.

111. Bloom, B.S.; Engelhart, M.D.; Furst, E.J.; Hill, W.H.; Krathwohl, D.R. A Taxonomy of Educational Objectives: The Classification of Educational Goals. In Handbook I the Cognitive Domain; Longmans, Green and Co.: Harlow, UK, 1956.

112. Stone, S.J. Instructors' Perceptions of Three-Dimensional (3D) Virtual Worlds: Instructional Use, Implementation and Benefits for Adult Learners; North Carolina State University: Raleigh, NC, USA, 2009.

113. Jordan, A.; Carlile, O.; Stack, A. Approaches to Learning: A Guide for Teachers; Open University Press: London, UK, 2008.

114. Kolb, D. Experiential Learning; Prentice-Hall: Englewood Cliffs, NJ, USA, 1984.

115. Brookfield, S. Understanding and Facilitating Adult Learning: Comprehensive Analysis of Principles and Effective Practices; Jossey-Bass: Hoboken, NJ, USA, 1991.

116. Knowles, M. The Modern Practice of Adult Education: From Pedagogy to Adragogy; Cambridge University School: Cambridge, UK, 1980.

117. Mezirow, J. Contemporary paradigms of learning. Adult Educ. Q. 1996, 46, 158-172. [CrossRef]

118. Pascual-Leone, J.; Irwin, R. Abstraction, the will, the self, and the modes of learning in adulthood. In Adult Learning and Development: Perspectives from Educational Psychology; Smith, M.C., Pourchot, T., Eds.; Lawrence Erlbaum Associates: Mahwah, NJ, USA, 1998; pp. 35-66.

119. Straka, G. Aprendizaje autodirigido en el mundo del trabajo. Rev. Eur. Form. Prof. 1997, 12, $93-98$.

120. Jobert, G. A inteligência no trabalho. In Tratado das Ciências e Das Técnicas da Formação; Instituto Piaget: Lisboa, Portugal, 2001.

121. Le Boterf, G. Da engenharia da formação à engenharia das competências: Que abordagens? Que actores? Que evoluções? In Tratado das Ciências e das Técnicas da Formação; Instituto Piaget: Lisboa, Portugal, 2001; pp. 355-373.

122. Ministério do Trabalho Solidariedade e Segurança Social (MTSSS). Decreto-Lei $n .{ }^{\circ} 14 / 2017$ de 26 de janeiro: Alteração ao regime jurídico do Sistema Nacional de Qualificações. In Diário da República; $1^{\mathrm{a}}$ série, n. ${ }^{\circ}$ 19; INCM: Lisboa, Portugal, 2017 ; pp. 508-518.

123. Ministério das Finanças (Mfin). Decreto-Lei n.o 86-A/2016 de 29 de Dezembro: Regime da Formação Profissional na Administração Pública. In Diário Da República 1a Série n. ${ }^{\circ}$ 249; 2016; pp. 30-40. Available online: https://dre.pt/application/file/a/105658 997 (accessed on 5 September 2021).

124. Comissão das Comunidades Europeias (CCE). Memorando Sobre Aprendizagem ao Longo da Vida; Comissão Europeia: Brussels, Belgium, 2000.

125. Caetano, A. Mudança Organizacional e Gestão de Recursos Humanos; Observatório do Emprego e Formação Profissional: Lisboa, Portugal, 1999.

126. Barbier, J. L'evaluation en Formation; Presses Universitaires de France: Paris, France, 1985.

127. Canário, R. Educação de Adultos: Um Campo e Uma Problemática; Educa: Lisboa, Portugal, 1999.

128. Cardim, J.; Miranda, R. Práticas de Formação Profissional, 2nd ed.; ISCSP: Lisboa, Portugal, 1998.

129. Ceitil, M. O papel da formação no desenvolvimento de novas competências. In Gestão de Recursos Humanos, 2nd ed.; Caetano, J.V., Ed.; RH Editora: Lisboa, Portugal, 2002.

130. Cruz, J. Formação Profissional em Portugal: Do Levantamento de Necessidades à Avaliação; Edições Sílabo: Lisboa, Portugal, 1998.

131. Meignant, A. A Gestão da Formação; Publicações Dom Quixote: Lisboa, Portugal, 1999.

132. Câmara, P.; Guerra, P.; Rodrigues, J. Humanator XXI, 7th ed.; Publicações Dom Quixote: Lisboa, Portugal, 2016.

133. Sweet, R. Work-based learning: Why? How? In Revisiting Global Trends in TVET: Reflections on Theory and Practice; UNESCOUNEVOC International Centre for Technical and Vocational Education and Training: Bonn, Germany, 2013 ; pp. 164-203.

134. Ministério da Administração Interna (MAI). Decreto-Lei n. ${ }^{\circ} 248 / 2012$ de 21 de novembro: Regime jurídico aplicável à constituição, organização, funcionamento e extinção dos corpos de bombeiros, no território continental. In Diário da República; $1^{\mathrm{a}}$ série, n. ${ }^{\circ} 225$; INCM: Lisboa, Portugal, 2012; pp. 6678-6689.

135. Agência Nacional para a Qualificação e o Ensino Profissional (ANQEP). Perfil Profissional Bombeiro/a. Bol. Trab. E Emprego 2008, 85, 1662-1666.

136. Ministério da Administração Interna (MAI). Despacho n. ${ }^{\circ} 5157 / 2019$ de 24 de maio: Regulamento dos cursos de formação, de ingresso e de acesso de bombeiro voluntário. In Diário da República; $2^{a}$ série, n. ${ }^{\circ}$ 100; INCM: Lisboa, Portugal, 2019; pp. 16152-16158.

137. Presidência do Conselho de Ministros (PCM). Despacho Conjunto n. ${ }^{\circ} 297 / 2006$ de 31 de março: Duração, conteúdo programático, sistema de funcionamento e de avaliação dos cursos de promoção. In Diário da República; $2^{\mathrm{a}}$ série, n. ${ }^{\circ}$ 65; INCM: Lisboa, Portugal, 2006; pp. 4815-4818.

138. Departamento de Desenvolvimento e Formação (DDF). Plano de Formação 2019. Formação e Desenvolvimento. 2019. Available online: https:/ / www.lisboa.pt/municipio/organizacao-municipal/recursos-humanos/formacao (accessed on 10 October 2021).

139. Tikly, L. Reconceptualizing TVET and development: A human capability and social justice approach. In Revisiting Global Trends in TVET: Reflections on Theory and Practice; UNESCO-UNEVOC International Centre for Technical and Vocational Education and Training: Bonn, Germany, 2013; pp. 1-39. 
140. Getha-Taylor, H.; Fowles, J.; Silvia, C.; Merritt, C.C. Considering the effects of time on leadership development. Public Pers. Manag. 2015, 44, 295-316. [CrossRef]

141. Fortin, M.; Coté, J.; Filion, F. Fundamentos e Etapas do Processo de Investigação; Lusodidacta: Loures, Portugal, 2009.

142. Saunders, M.N.K.; Lewis, P.; Thornhill, A. Research Methods for Business Students, 8th ed.; Pearson: Harlow, UK, 2019.

143. Hill, M.; Hill, A. Investigação por Questionário, 2nd ed.; Edições Sílabo: Lisboa, Portugal, 2016.

144. Norwood, S. Research Strategies for Advanced Practice Nurses; Prentiss Hall: Upper Saddle River, NJ, USA, 2000.

145. Bryman, A. Social Research Methods, 5th ed.; Oxford University Press: Oxford, UK, 2016.

146. Marôco, J. Análise Estatística com o SPSS Statistics, 7th ed.; Report Number: Pêro Pinheiro, Portugal, 2018.

147. Laureano, R. Teste de Hipóteses com o SPSS—o meu Manual de Consulta Rápida, 2nd ed.; Edições Sílabo: Lisboa, Portugal, 2013.

148. Fisher, R. Statistical Methods and Scientific Inference; Collins Macmillan: New York, NY, USA, 1973.

149. Vilelas, J. Investigação—o Processo de Construção do Conhecimento, 2nd ed.; Edições Sílabo: Lisboa, Portugal, 2017. 